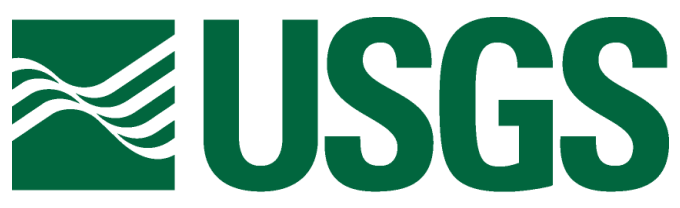

science for a changing world

\title{
Digital depth horizon compilations of the Alaskan North Slope and adjacent arctic regions
}

by R.W. Saltus ${ }^{1}$ and K.J. Bird ${ }^{2}$

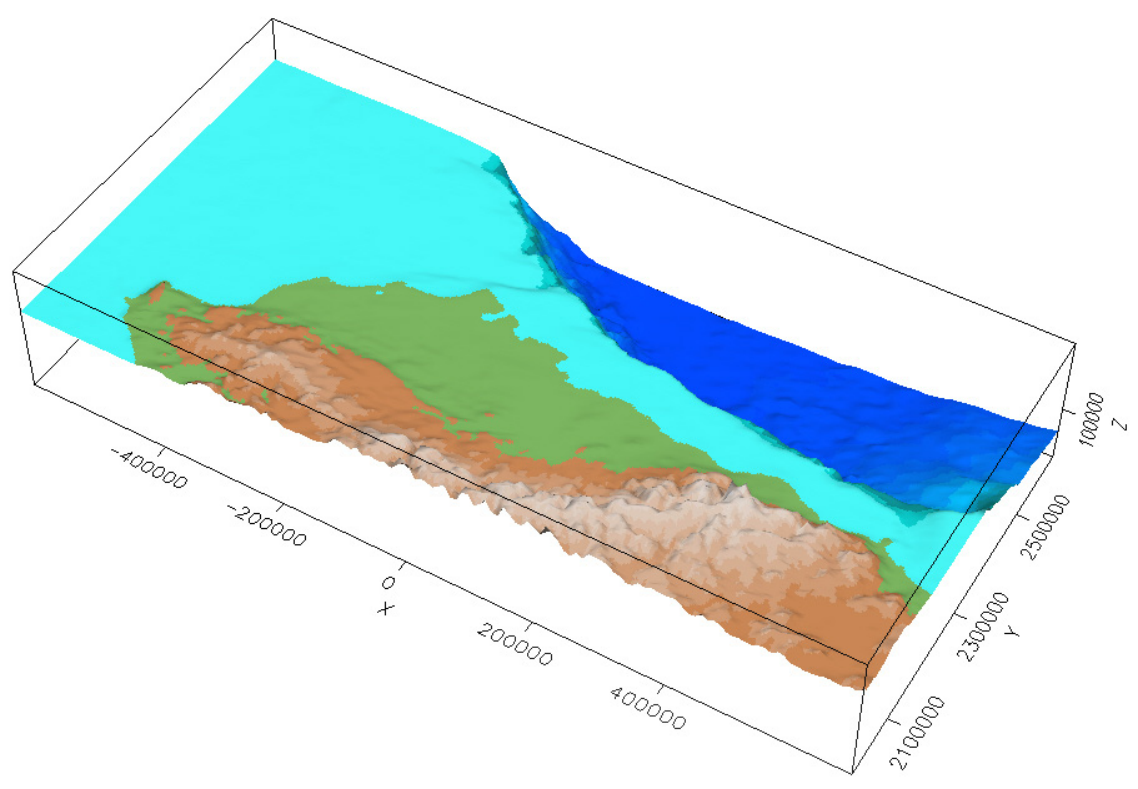

Open-File Report 03-230

2003

This report is preliminary and has not been reviewed for conformity with U.S. Geological Survey editorial standards or with the North American Stratigraphic Code. Any use of trade, firm, or product names is for descriptive purposes only and does not imply endorsement by the U.S. Government.

\section{U.S. DEPARTMENT OF THE INTERIOR}

U.S. GEOLOGICAL SURVEY

${ }^{1}$ U.S. Geological Survey, Denver, Colorado.

${ }^{2}$ U.S. Geological Survey, Menlo Park, California. 


\section{Abstract}

Data have been digitized and combined to create four detailed depth horizon grids spanning the Alaskan North Slope and adjacent offshore areas. These map horizon compilations were created to aid in petroleum system modeling and related studies. Topography/bathymetry is extracted from a recent Arctic compilation of global onshore DEM and satellite altimetry and ship soundings offshore. The Lower Cretaceous Unconformity (LCU), the top of the Triassic Shublik Formation, and the preCarboniferous acoustic basement horizon grids are created from numerous seismic studies, drill hole information, and interpolation. These horizons were selected because they mark critical times in the geologic evolution of the region as it relates to petroleum. The various horizons clearly show the major tectonic elements of this region including the Brooks Range, Colville Trough, Barrow Arch, Hanna Trough, Chukchi Platform, Nuwuk Basin, Kaktovik Basin, and Canada Basin. The gridded data are available in a variety of data formats for use in regional studies.

\section{Introduction}

The Alaskan North Slope and adjacent regions of the Chukchi and Beaufort Seas (Figure 1) are believed to contain significant volumes of undiscovered hydrocarbon resources. This belief is bolstered by the known occurrence of major oil and gas resources in the greater Prudhoe Bay area. Significant volumes of hydrocarbon resources have been estimated in recent assessments of the National Petroleum Reserve Alaska (NPRA; Bird and Houseknecht, 2002), the 1002 area of the Arctic National Wildlife Refuge (ANWR; ANWR Assessment Team, 1998), and the federal offshore (Sherwood and others, 1998). Refinement and areal extension of resource estimates requires understanding and modeling of the tectonic and sedimentologic evolution of the region as well as derivative information on hydrocarbon generation, migration, and trapping processes in the greater basin region that encompasses the Alaskan North Slope and offshore areas. As a basis for such studies, including detailed modeling of basin formation and fluid movement (petroleum system modeling, see Magoon and Dow, 1994) and regional geophysical studies (e.g., Saltus and others, 2001), we have assembled digital compilations defining four depth horizons: present-day topography/bathymetry, the Lower Cretaceous unconformity, the Triassic Shublik Formation, and the pre-Carboniferous acoustic basement. These four horizons were selected because they mark critical times in the development of the petroleum prospective rocks making up this region. In this report we document the data compilations, and describe the primary features of each depth horizon and of the isopachs between these horizons. We also compare our results with a previous isopach compilation by Hubbard and others (1990). This report documents the displays previously presented by Saltus and Bird (2003). 


\section{Geography/Tectonic Features}

Major tectonic features (Fig. 1) within the North Slope data compilation area include the northern portion of the Brooks Range Orogenic Belt, the Colville (foreland) Basin and intersecting Hanna Trough, the Barrow and Herald Arches, the North Chukchi Basin, and the offshore Canada Basin. For a discussion of the tectonic significance of many of these features see Moore and others (1994), Grantz and others (1990b), and Hubbard and others (1990). These features influence the digital horizons compiled for this report.

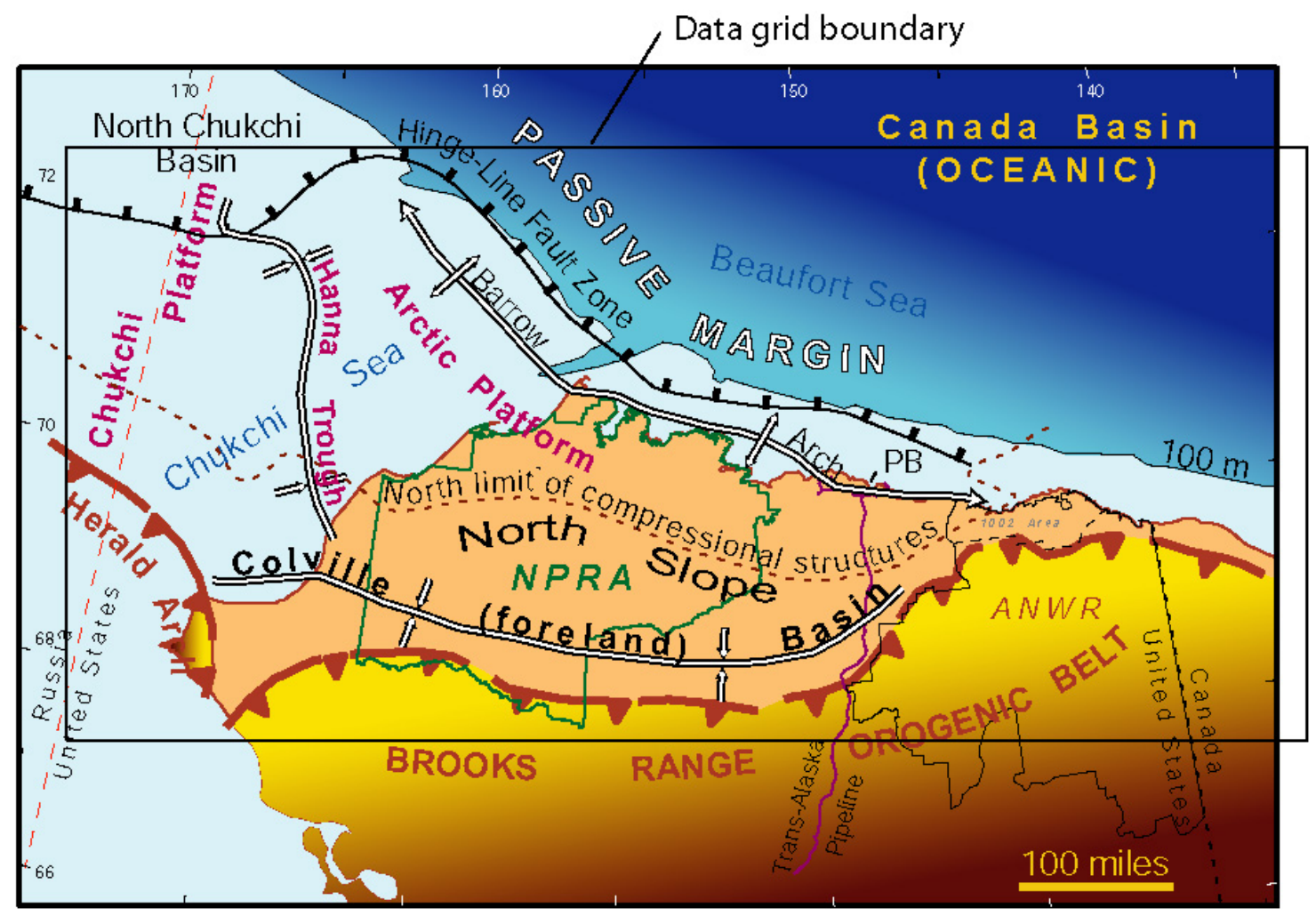

Figure 1. Map showing the location of the North Slope data grid compilation area relative to major tectonic features of northern Alaska. ANWR, Arctic National Wildlife Refuge. NPRA, National Petroleum Reserve Alaska. PB, Prudhoe Bay. 


\section{Compilation of depth horizons}

Available data for four depth horizons (Fig. 2): (1) present-day topography/bathymetry, (2) Lower Cretaceous unconformity (LCU), (3) top of Triassic Shublik Formation, and (4) pre-Carboniferous basement were digitally assembled for the study area. The details of the compilation steps are discussed below for each horizon.

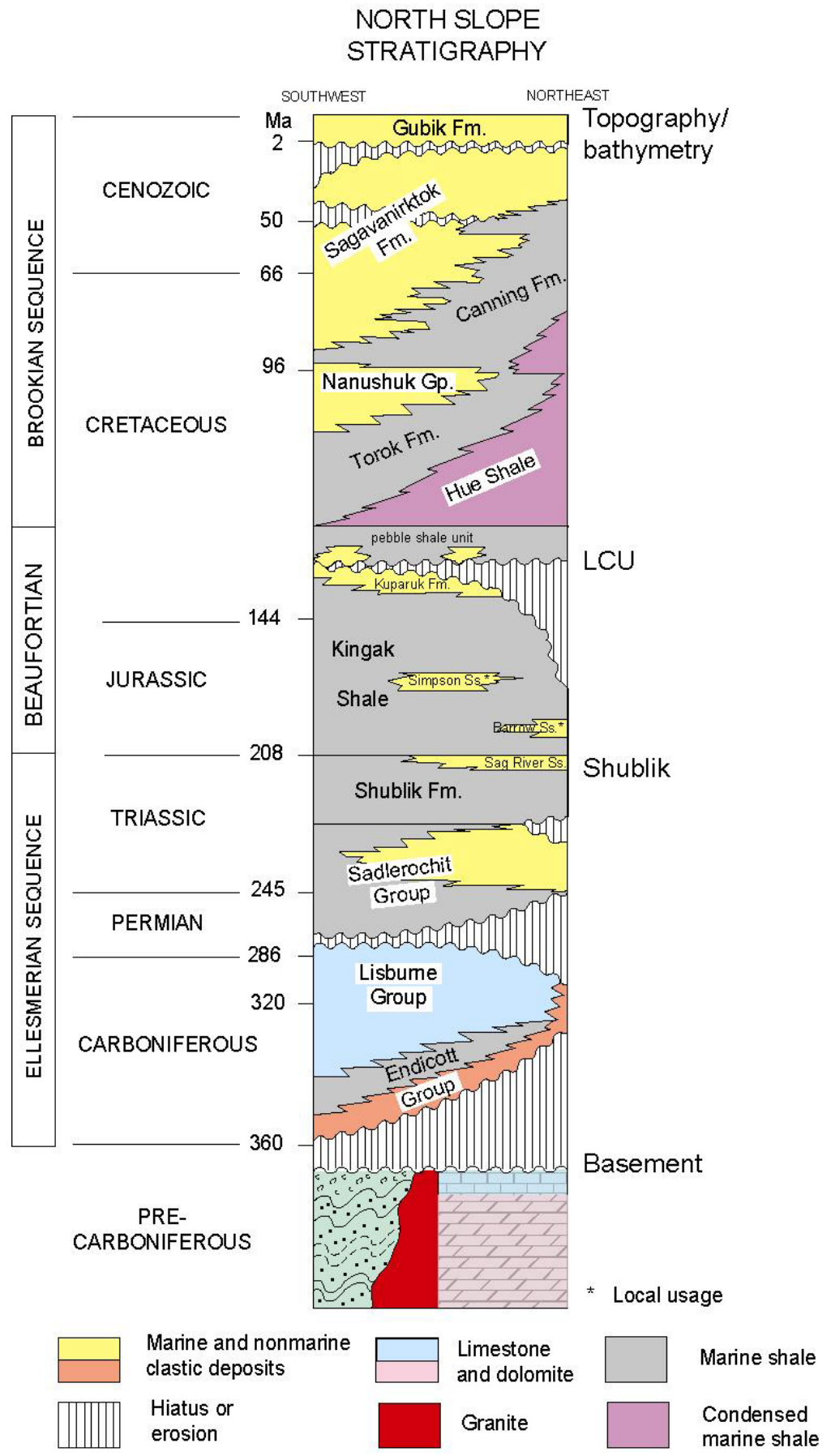

Figure 2 - Generalized North Slope stratigraphy (based on Bird, 1988). 
The study area (Fig. 3) comprises an area of $814,320 \mathrm{~km}^{2}$ that includes all of Alaska north of $68^{\circ} \mathrm{N}$, along with significant portions of the Chukchi Sea, Arctic Ocean, and Beaufort Sea north to about $73^{\circ} \mathrm{N}$. At the southern edge, the study area spans from about $168^{\circ} \mathrm{W}$ to $138^{\circ} \mathrm{W}$. The size of the area was selected to obtain a regional view that encompasses the entire North Slope. The data grids have $3000 \mathrm{~m}$ cells, span 435 columns east to west and 208 rows south to north, and are defined relative to an Albers EqualArea projection having the following specifications: central meridian $=154^{\circ} \mathrm{W}$, base latitude $=50^{\circ} \mathrm{N}$, standard parallels $=55^{\circ} \mathrm{N}$ and $65^{\circ} \mathrm{N}$. The NAD27 datum was used. The projected $\mathrm{x}$ (easting) and $\mathrm{y}$ (northing) coordinates (in meters) of the center of the southwest grid cell are $-630000,2000000$. The projected coordinates of the center of the northeast grid cell are 672000,2621000 . Thus, an image defined by these grid values spans an area of 1,305 km east to west and $624 \mathrm{~km}$ south to north.

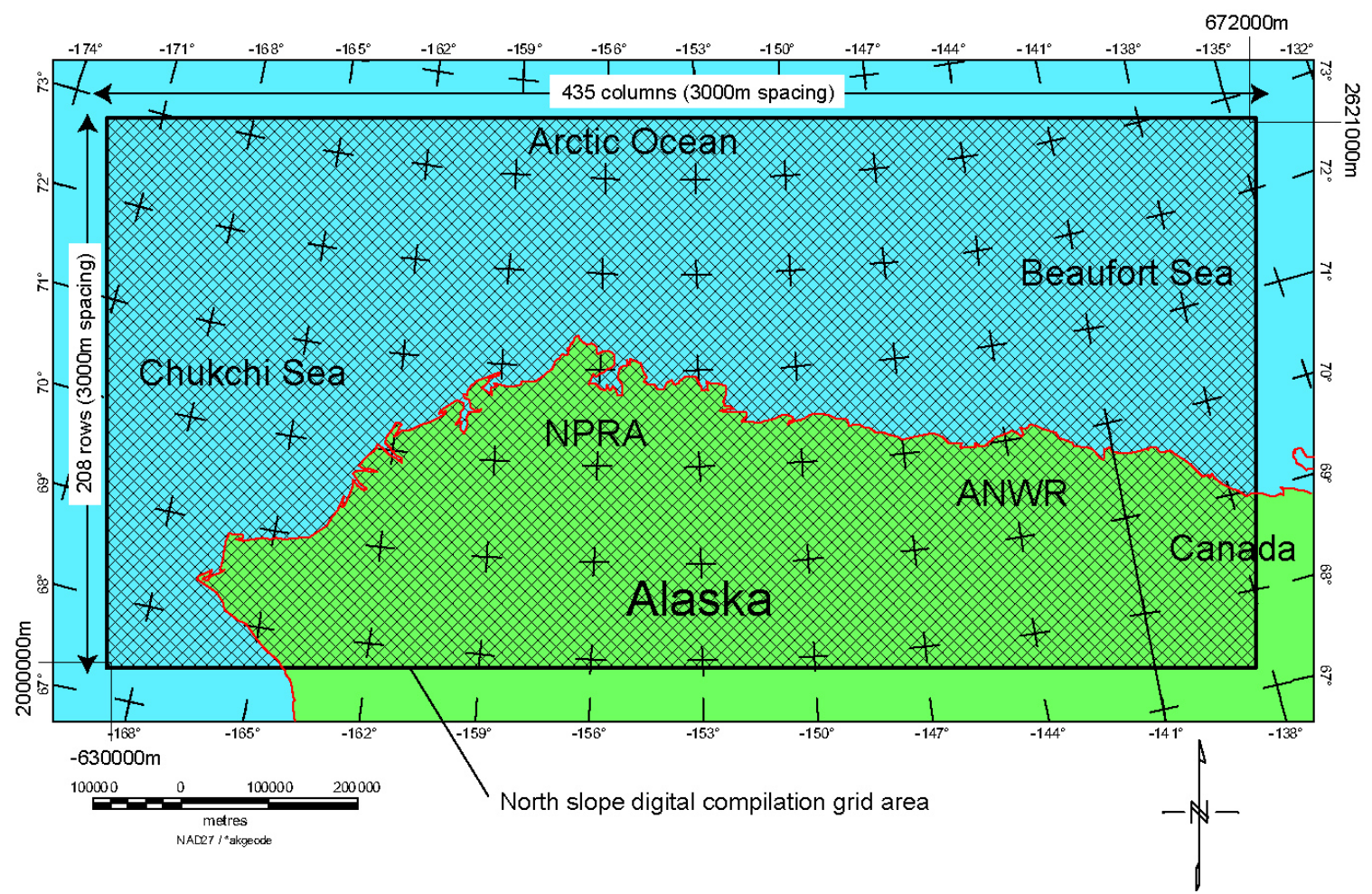

Figure 3 - Index map showing North Slope digital compilation grid area boundaries and size. 
Except for the topography/bathymetry horizon, each of the depth horizons was compiled from multiple data sources. In general, data for each individual source were gridded separately to produce component grids that were subsequently merged to form the composite grid. The random gridding utility of the Oasis montaj 5.1.6 (Geosoft, Inc.) geophysical software package was used for data gridding. This utility is based on refinements to the minimum curvature method first outlined by Briggs (1974). Grid merging was performed using the Oasis montaj 5.1.6 gridstch utility. Grids were merged pairwise in the order indicated in each section below. Two grid-stitching parameters were used to control the amoothing adjustments made to grid values at the boundary between the two grids: weighting and correction width. Weighting is set to a value between 0 and 1. A value of 0 causes all adjustments to be applied to the first grid. A value of 1 causes all adjustments to be applied to the second grid. The correction width is also specified for each merge. This is the distance over which any edge adjustments are made to smooth the transition between the two component grids.

\section{Topography/bathymetry}

The digital topography/bathymetry grid was extracted from the International Bathymetric Chart of the Arctic Ocean (IBCAO), version 1.0

(http://www.ngdc.noaa.gov/mgg/bathymetry/arctic/arctic.html). The offshore portion of this compilation is from ship track data and Russian bathymetric maps. The onshore portion is extracted from GTOPO30, a global digital elevation model with horizontal data spacing of about $1 \mathrm{~km}$ that was completed in late 1996 by an international collaboration lead by the EROS Data Center of the USGS.

The IBCAO grid was prepared using the Polar Stereographic projection and a grid interval of $2.5 \mathrm{~km}$. We reprojected a subset of the grid into the Alaska Albers projection for this project using the Oasis montaj geophysical processing package by Geosoft, Inc., Toronto, Canada.

The topography/bathymetry depth horizon ranges from 2160 meters above sea level to about 3880 meters below sea level (Fig. 4). The Brooks Range encompasses the highest elevations. The coastal plain and foothills span regions from sea level to several hundred meters elevation. The Chukchi Sea is shallow, reaching a maximum depth of about 100 meters below sea level. The Arctic Ocean basin reaches depths of 3500 meters and more below sea level. 


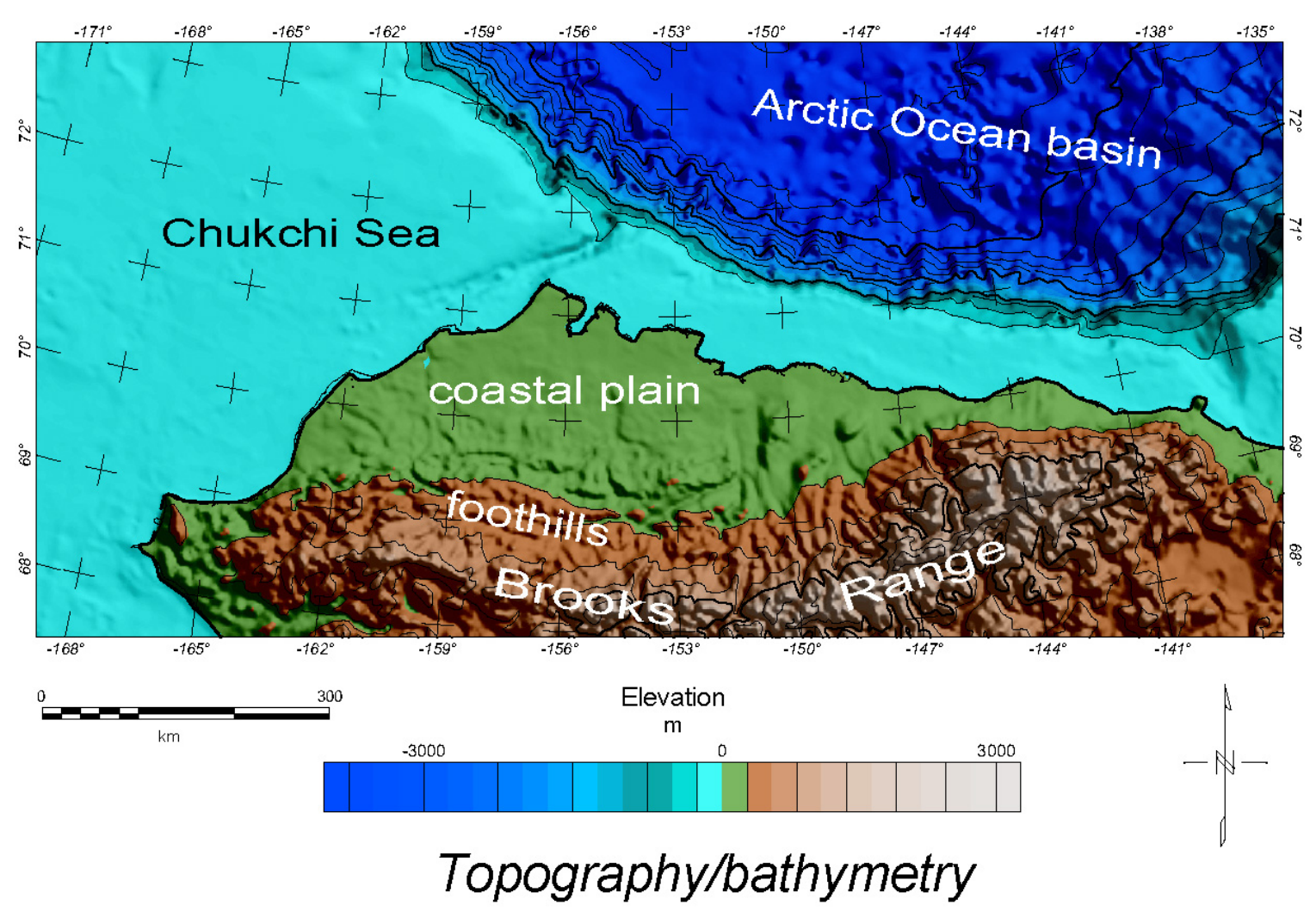

from the International Bathymetric Chart of the Arctic Ocean, beta version

Figure 4 - Shaded relief view of the topography/bathymetry grid.

\section{Lower Cretaceous Unconformity}

In the geologic history of northern Alaska, the Lower Cretaceous Unconformity (LCU) represents the culmination of an episode of rifting and the onset of seafloor spreading in the Arctic Ocean (Grantz and May, 1988). The LCU also marks the base, for all practical purposes, of the Brookian foreland basin and passive margin depositional episode. The LCU grid was assembled from a variety of sources and the basement and topographic horizons where appropriate (Fig. 5). Within the NPRA (A, Fig. 5) the data are from the USGS update (Saltus and others, 2002) of 1980s vintage seismic mapping (Bruynzeel and others, 1982). In the Chukchi Sea region (C, Fig. 5), data were digitized from plate 13.2 of Sherwood and others (1998). To the east of NPRA (B, Fig. 5), the central north slope region data are a composite based on projections of depth contours from NPRA and ANWR, well penetrations, and limited seismic control provided by Tailleur and others (1978a). The offshore region, south of the Ellesmerian pinchout (E1 and part of G1, Fig. 5 ), is made up of data digitized from figure 4 of Grantz and others (1990a) and from plate 1 of Grantz and others (2002). The digitized data from Grantz and others (2002) were modified on the Harold Arch (Fig. 1) to reflect the position of the arch on figure 4 of Grantz and others (1990a). North of the pinchout of Ellesmerian strata (G1, E2, G2, H, Fig. 5), the LCU surface is the same as the basement and is defined by the basement horizon in that region. Similarly, south of the Brooks Range mountain front (F, Fig. 5), the LCU horizon intersects the surface and is arbitrarily defined to the south by 
topography. Hand-drawn contours, based on limited well and seismic control, were used to fill in several areas adjacent to NPRA (D1, D2, D3, Fig. 5).

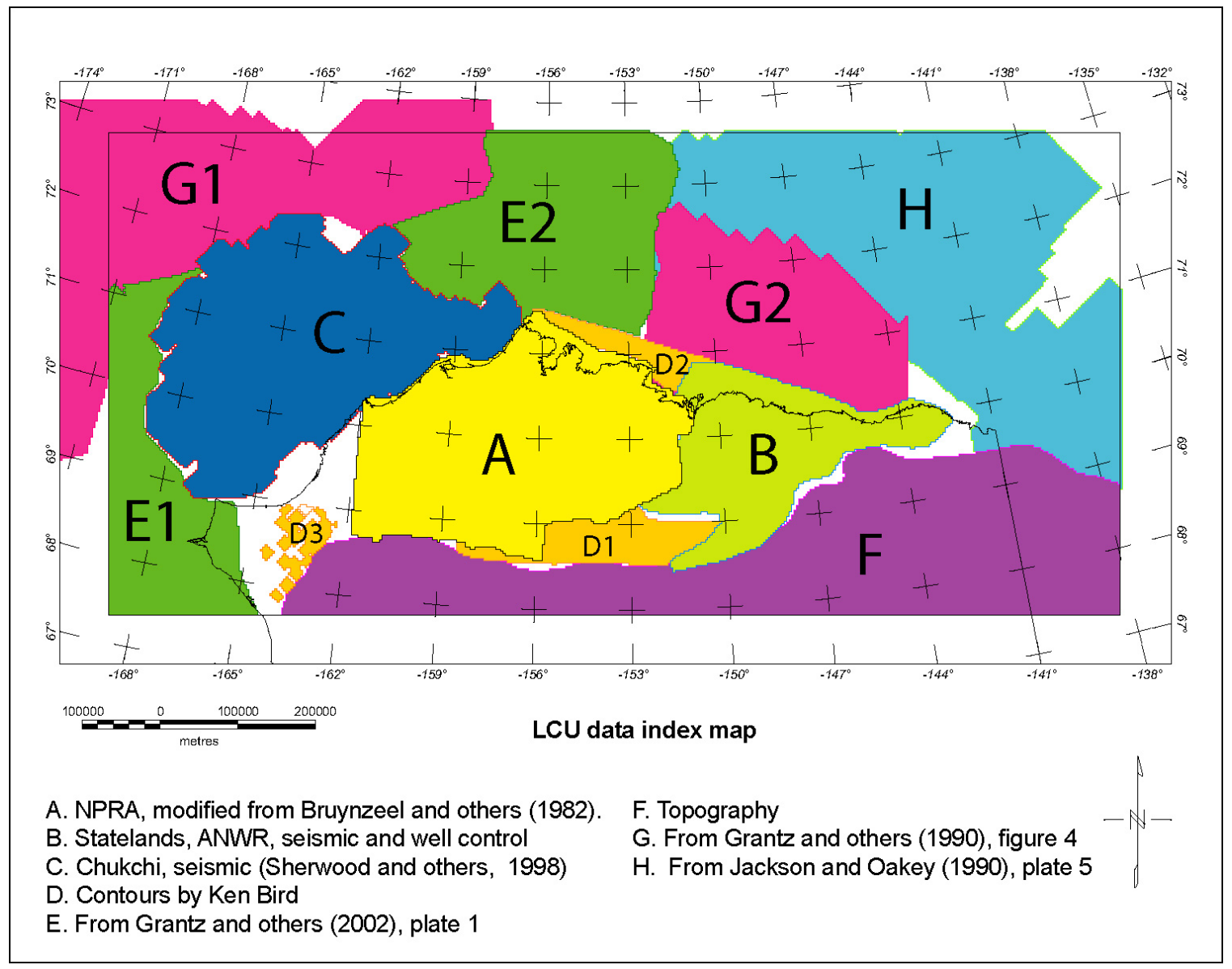

Figure 5 - Index map to data sources for the LCU grid compilation.

The LCU horizon was assembled as follows (refer to Fig. 5):

1. $\mathrm{A}+\mathrm{B}$ (overlap weighting 0.5 , smoothing over $96 \mathrm{~km}$ )

2. $+\mathrm{C}$ (overlap weighting 0.5 , smoothing over $96 \mathrm{~km}$ )

3. + D1, D2, D3 (overlap weighting 0.8, smoothing over $96 \mathrm{~km}$ )

4. + E1, E2 (overlap weighting 0.8 , smoothing over $27 \mathrm{~km}$ )

5. $+\mathrm{F}$ (overlap weighting 0.8 , smoothing over $27 \mathrm{~km}$ )

6. + G1, G2 (overlap weighting 0.8 , smoothing over $96 \mathrm{~km}$ )

7. $+\mathrm{H}$ (overlap weighting 0.8 , smoothing over $96 \mathrm{~km}$ )

After merging several rough data boundaries were clipped out and regridded to remove merge artifacts. Care should be taken not to over interpret any remaining features at data boundaries. 
The Lower Cretaceous Unconformity (LCU) depth horizon (Fig. 6) intersects the topographic surface along the Brooks Range mountain front. To the south of the Brooks Range mountain front, the LCU grid equals topography. To the north of the Brooks Range mountain front, the LCU reaches depths greater than $10 \mathrm{~km}$ below sea level in the Colville Basin. Continuing north, the LCU climbs to the Barrow Arch. In most places north of the Barrow arch the LCU is the same as basement (in other words, there is little or no Beaufortian or Ellesmerian section present).

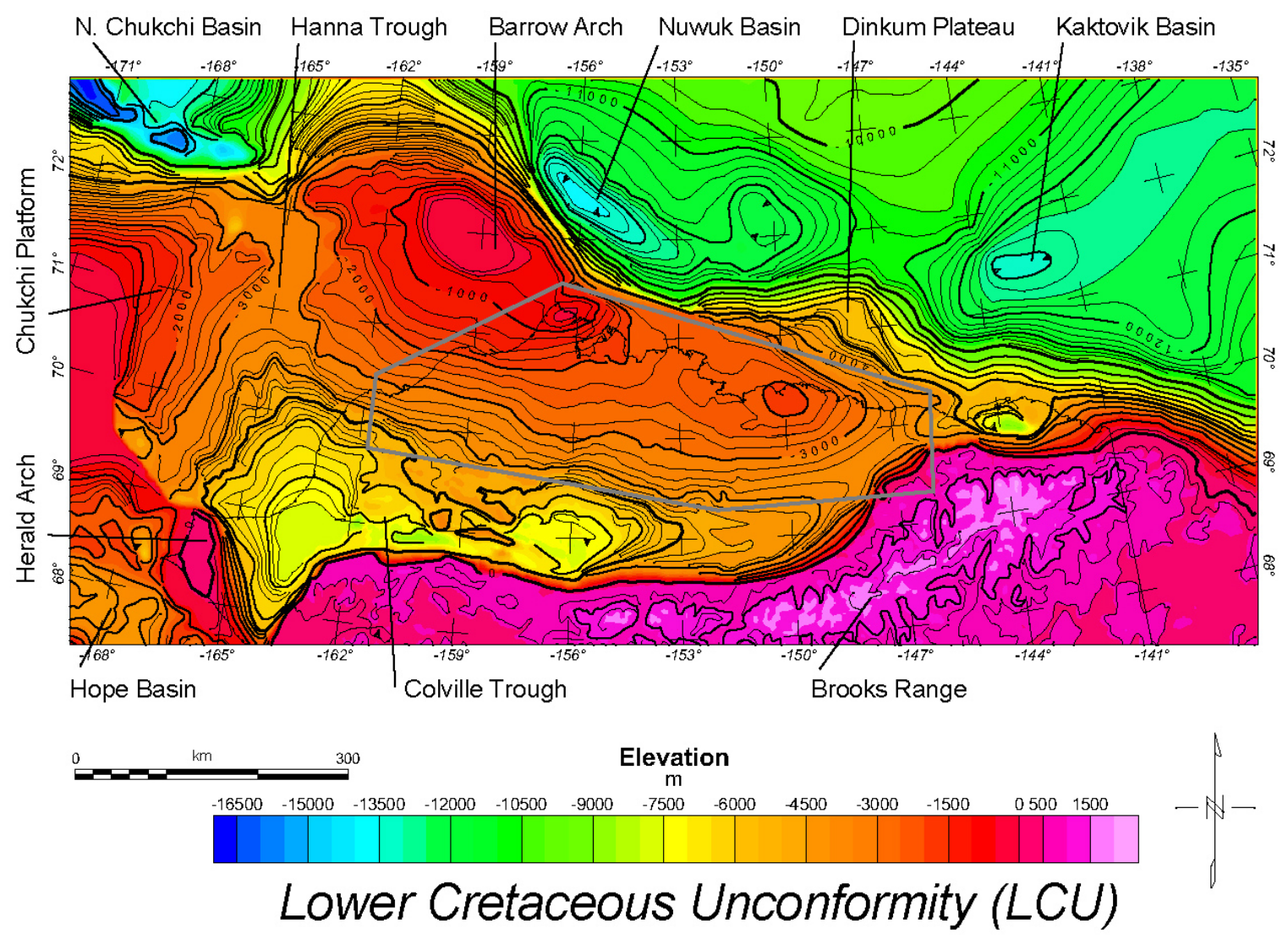

Figure 6 - Colored contour map of the Lower Cretaceous Unconformity (LCU). The gray line delineates the Petromod polygon - the region of preliminary hydrocarbon flow models undertaken by the USGS (Lampe and others, 2003).

\section{Top of Shublik}

The top of the Shublik Formation is a prominent, readily mapped, seismic reflector that typically lies within $30 \mathrm{~m}$ of the top of the late Paleozoic-early Mesozoic passive continental margin succession known as the Ellesmerian sequence. The Shublik Formation has limited areal distribution that is controlled by stratigraphic onlap, pinchout, and removal by erosional unconformity. The NPRA region (A, Fig. 7) is from the USGS update (Saltus and others, 2002) of 1980s vintage seismic mapping (Bruynzeel and others, 1982). In the Chukchi Sea region (C, Fig. 7) data were digitized from figure 13.22 in Sherwood and others (1998). To the east of NPRA (B, Fig. 7), we prepared and digitized a map based on an extrapolation eastward from the NPRA Shublik horizon using the overlying Sag River and underlying Sadlerochit horizons as guides and using 
well penetrations more recent than the published maps (Pessel and others, 1978; Tailleur and Engwicht, 1978). The Barrow Arch regions of A and B (see Fig. 1) were adjusted slightly (maximum change about $400 \mathrm{~m}$ ) to match well control in that area.

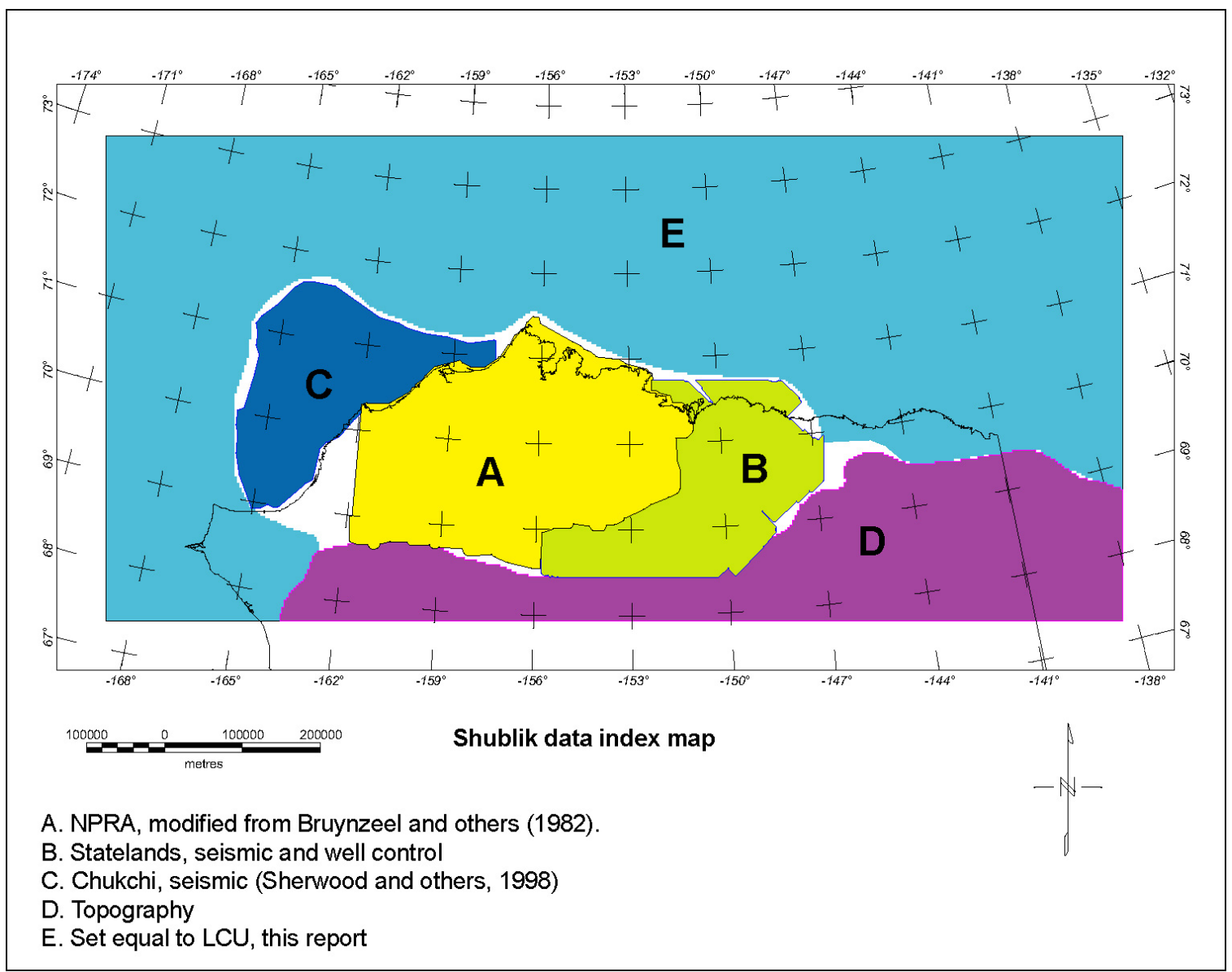

Figure 7. Index map to data sources for the top of Shublik data compilation.

The Shublik horizon was assembled as follows (refer to Fig. 7):

1. $\mathrm{A}+\mathrm{B}$ (overlap weighting 1.0, smoothing over $96 \mathrm{~km}$ )

2. $+\mathrm{C}$ (overlap weighting 1.0, smoothing over $48 \mathrm{~km}$ )

3. $+\mathrm{D}$ (overlap weighting 0 , smoothing over $9 \mathrm{~km}$ )

4. + E (set grid values equal to LCU horizon)

White areas were filled in by minimum curvature interpolation.

The Shublik Formation is generally present only in the area south of the Barrow Arch and east of the Chukchi Platform (Fig. 8). The limits, both north and west, are combinations of stratigraphic onlap (pinchout) or removal by erosional unconformities. North and west of these limits, the Shublik horizon merges with the LCU horizon. To the south of the Brooks Range mountain front, the Shublik grid equals topography. 


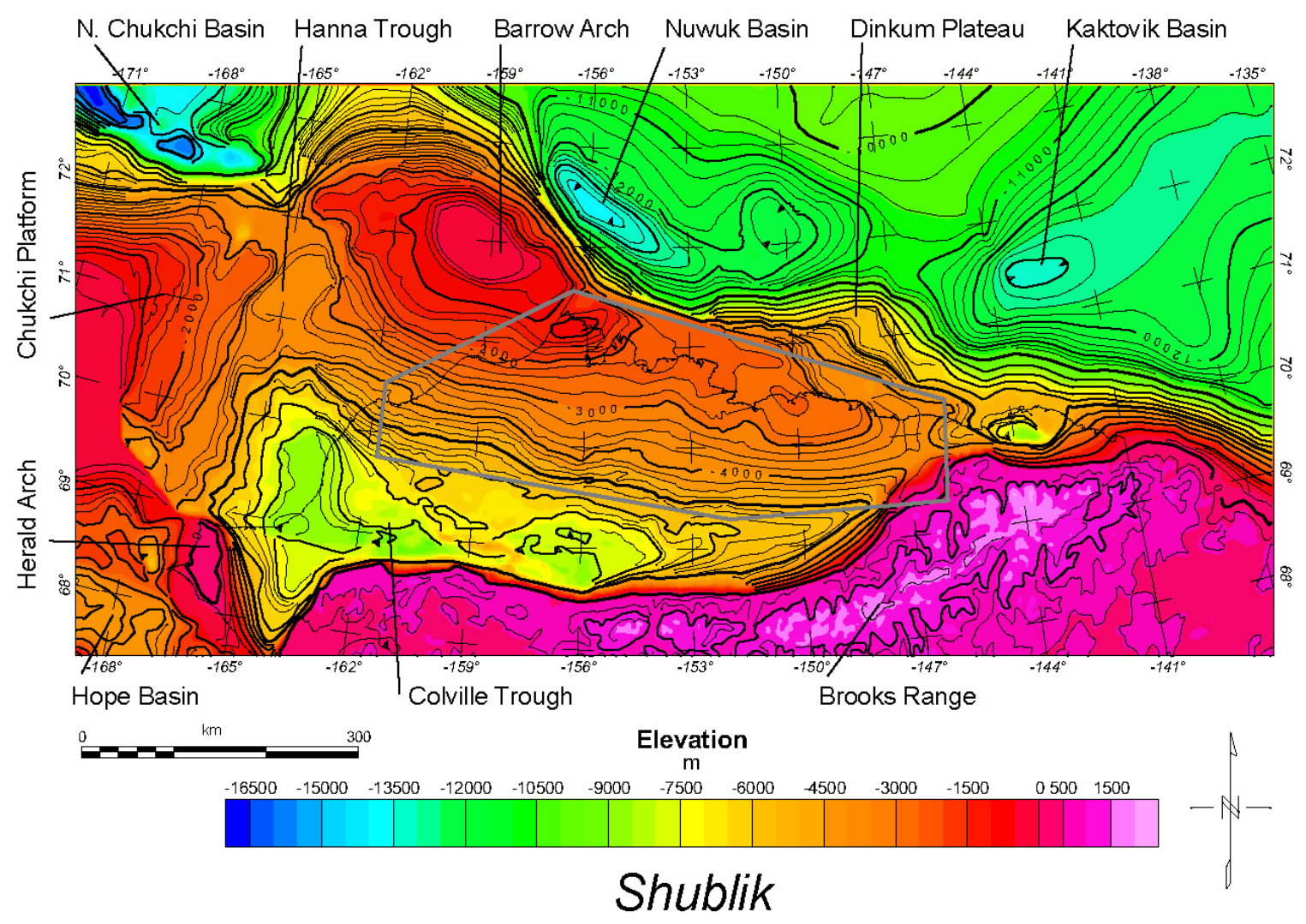

Figure 8. Colored contour map of elevation of the top of the Shublik horizon. The gray polygon is the region of preliminary USGS hydrocarbon flow models (Lampe and others, 2003).

\section{Seismic basement}

The basement surface marks an erosional unconformity that developed after a Devonian orogenic event that resulted in region-wide folding and faulting. This surface generally represents both acoustic basement and, because of its inferred thermal history, economic basement for petroleum as well. The gridded seismic basement horizon (depth to preCarboniferous rocks) is based on data from eight sources including topography where basement is exposed at the surface (Fig. 9). The NPRA region (A, Fig. 9) is from the USGS update (Saltus and others, 2002) of 1980s vintage seismic mapping (Bruynzeel and others, 1982). In the Chukchi Sea region (D, Fig. 9), data were digitized from plate 13.1 of Sherwood and others (1998). The seismically reflective pre-Carboniferous rocks of the Northeast Chukchi basin (Craig and others, 1985) are an exception and were excluded by Sherwood and others (1998) from this definition of seismic basement. In other words, Sherwood and others (1998) defined basement at the top of the preCarboniferous rocks rather than the base of stratified seismic reflectors. To the east of NPRA (B, Fig. 9), the basement horizon is based on projections from NPRA and ANWR, well penetrations, and limited seismic control from Tailleur and others (1978b). In the coastal plain region of ANWR (C, Fig. 9), seismic basement is from USGS interpretation of proprietary industry seismic data. Finally, in the offshore region, basement was calculated by subtracting sedimentary thicknesses from Jackson and Oakey (1990) from 
the topography/bathymetry data grid (H, Fig. 9) and from compilations by Grants and others (1990; 2002; F, G, Fig. 9).

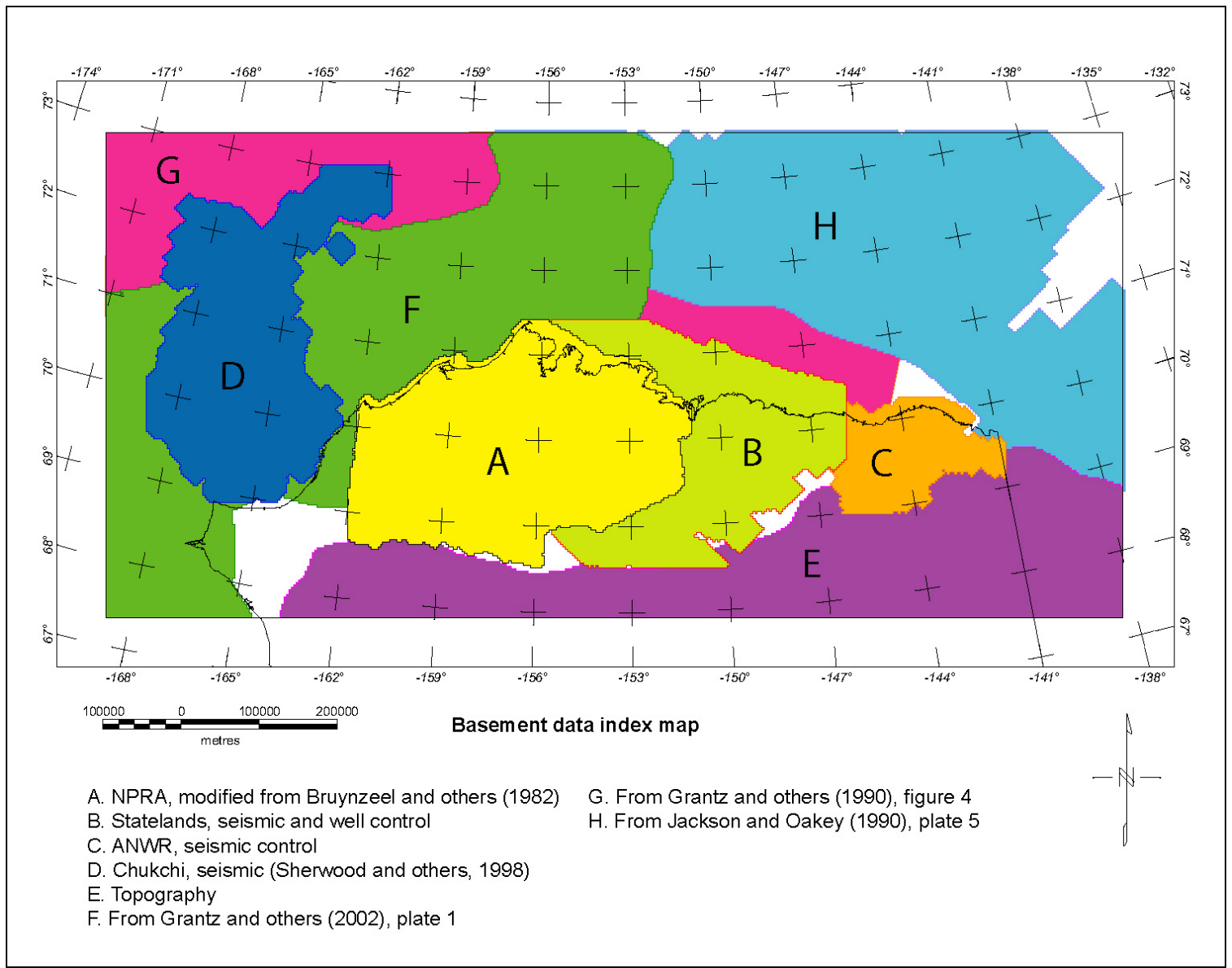

Figure 9 - Index map to data sources for the pre-Carboniferous basement compilation.

The seismic basement horizon was assembled as follows (refer to Fig. 9):

1. $\mathrm{A}+\mathrm{B}$ (overlap weighting 0.5 , smoothing over $96 \mathrm{~km}$ )

2. $+\mathrm{C}$ (overlap weighting 0.5 , smoothing over $96 \mathrm{~km}$ )

3. $+\mathrm{D}$ (overlap weighting 0.5 , smoothing over $96 \mathrm{~km}$ )

4. $+\mathrm{E}$ (overlap weighting 1.0, smoothing over $15 \mathrm{~km}$ )

5. $+\mathrm{F}+\mathrm{G}+\mathrm{H}$ (this region extracted from the LCU compilation, overlap weighting 1.0 , smoothing over $48 \mathrm{~km}$ )

White areas were filled in by minimum curvature interpolation or filled in from the LCU compilation.

Pre-Carboniferous rocks are discontinuously exposed at the surface to the south of the Brooks Range mountain front. However, we arbitrarily set basement to equal topography as was done with the other subsurface horizons (Fig. 10). To the north of the Brooks Range mountain front the pre-Carboniferous basement is deeper than $12 \mathrm{~km}$ below sea level in the parts of the Colville basin. Basement comes to within about $500 \mathrm{~m}$ of the surface at the culmination of the Barrow arch. North of the Barrow arch, basement 
descends to a depth of nearly $14 \mathrm{~km}$ along the rifted margin before rising up to about 10 $\mathrm{km}$ in the north-central portion of the study area. North of the rifted margin, basement is postulated to be Early Cretaceous oceanic crust rather than pre-Carboniferous (Grantz and others, 1990b).

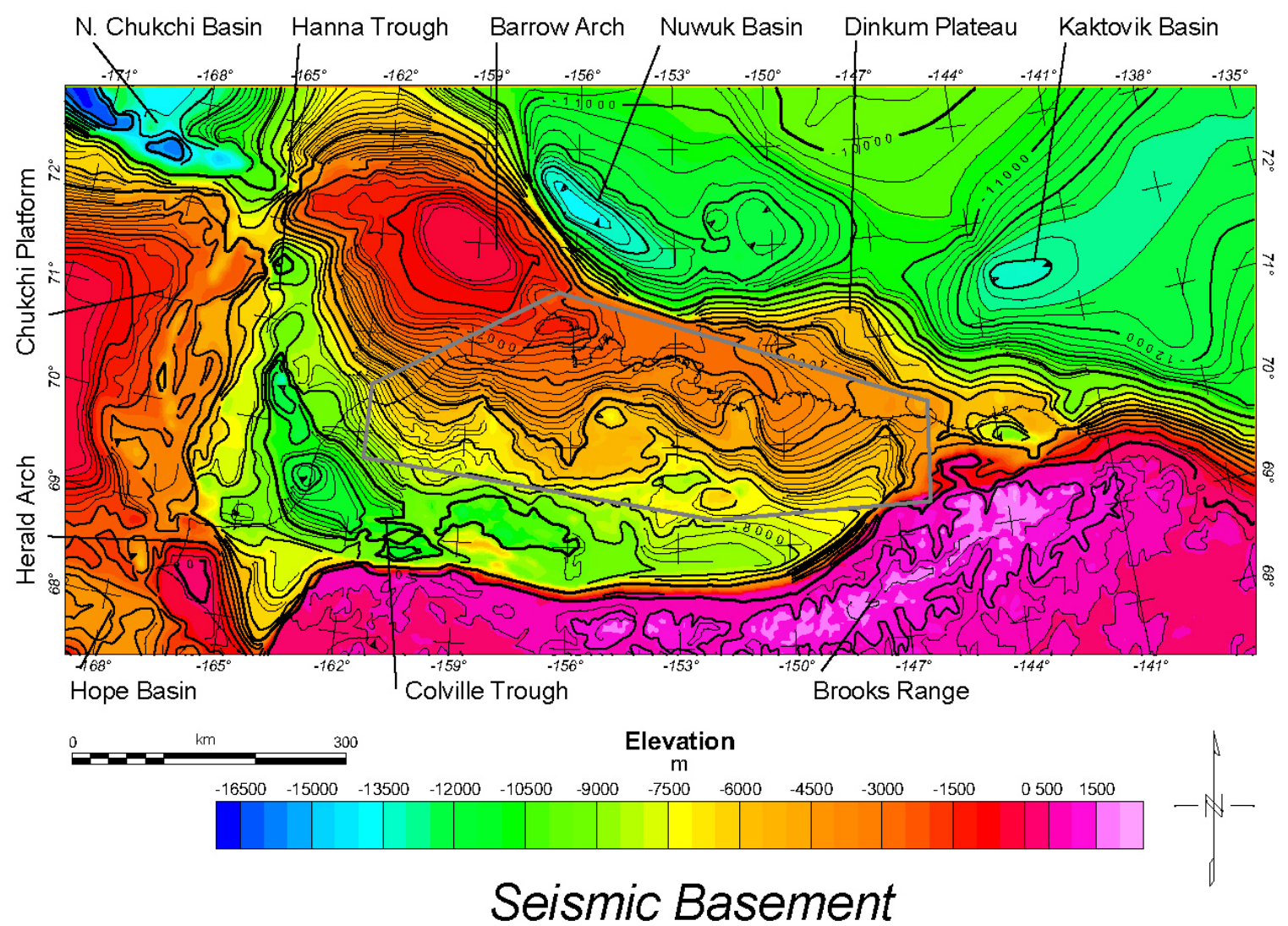

Figure 10 - Colored contour map of elevation of the pre-Carboniferous basement horizon. The gray polygon is the region of preliminary USGS hydrocarbon flow models (Lampe and others, 2003). 


\section{Isopachs}

The following isopach grids were constructed by subtracting the four horizon grids from each other. In areas of the map where data were sparse and interpolations necessary, isopach values may be significantly in error. These isopachs generally compare favorably with, but are significantly more detailed than, previous isopachs compiled by Hubbard and others (1990).

\section{Surface to LCU (Brookian) interval}

The Brookian interval (Fig. 2) is thickest in the offshore Nuwuk Basin, the north Chukchi Basin, the Kaktovik Basin region, and in the deepest portions of the Colville Trough (Fig. 11). Compared with the earlier compilation by Hubbard and others (1990, Fig. 20), our compilation shows significantly more detail. In sharp contrast to the through-going offshore trough in the Brookian isopach map by Hubbard and others (1990, Fig. 20), we show the discrete and separate Nuwuk and Kaktovik Basins of Grantz and others (1990, Fig. 4). We also show a more pronounced embayment in the southwestern portion of the Colville Trough to the east of the Herald Arch. This embayment is not constrained by any data, however.

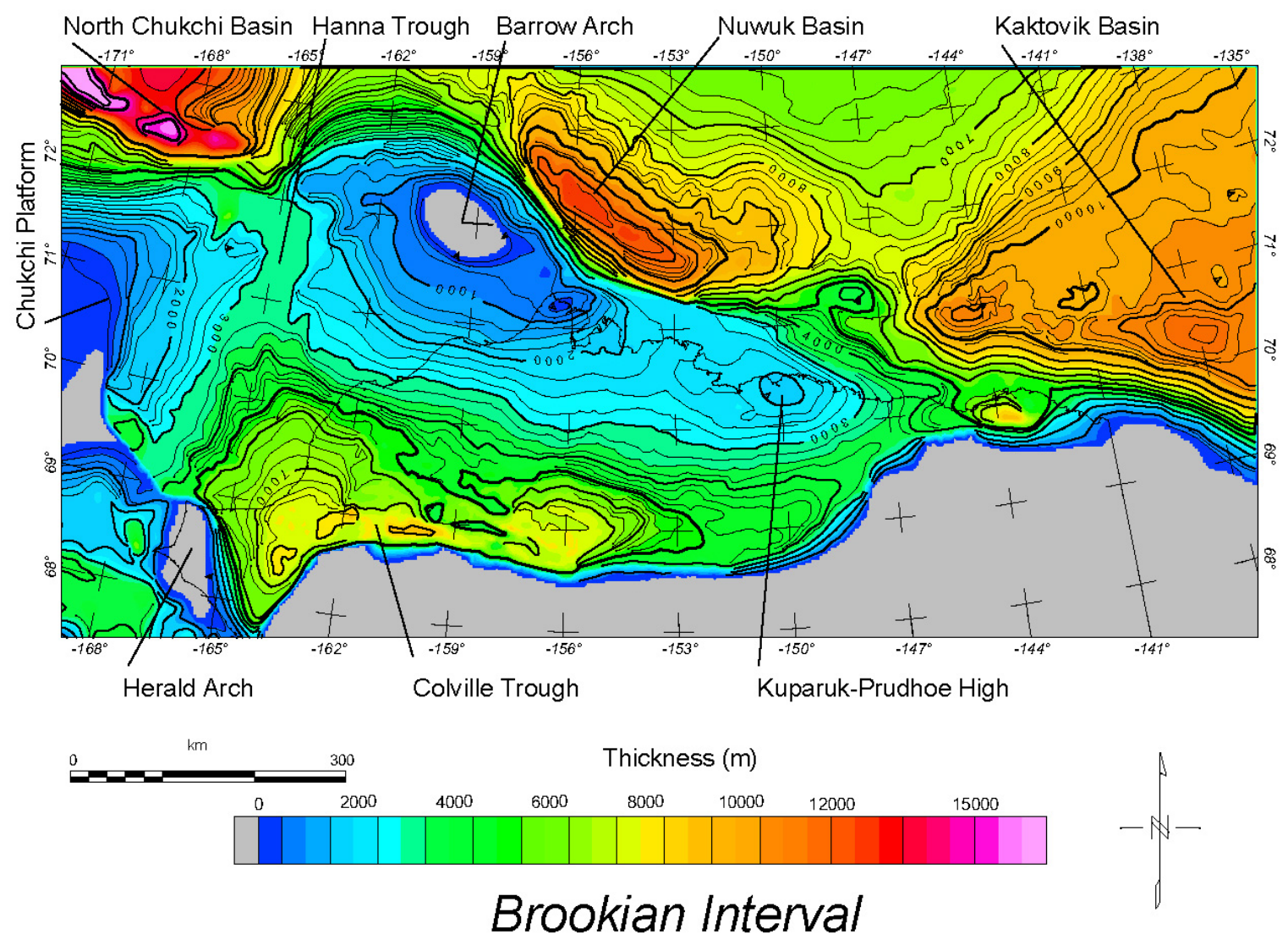

Figure 11 - Color contour isopach map of the Brookian stratigraphic interval. 


\section{LCU to top of Shublik (Beaufortian) interval}

The Beaufortian section (Fig. 12) thickens southward toward the Colville Basin, reaches a maximum, and begins to thin near the front of the Brooks Range (locations labeled on Fig. 1). It is particularly thick in the southern portion of the Chukchi Sea, possibly an artifact resulting from data extrapolation into this region. Compared with the earlier compilation by Hubbard and others (1990, Fig. 13), our isopach is considerably more detailed in the Colville Basin and eastern Chukchi Sea regions (Fig. 12). In particular, we show the thickest portions of the isopach to be more extensive in the southern portions of the Colville Trough than shown by Hubbard and others (1990, Fig. 13). We show the Dinkum Graben as a much thinner feature than Hubbard and others (1990, Fig. 13). North of Barrow (location A, Fig. 12) we only map a small portion of a broader trough indicated by Hubbard and others (1990, Fig. 13).

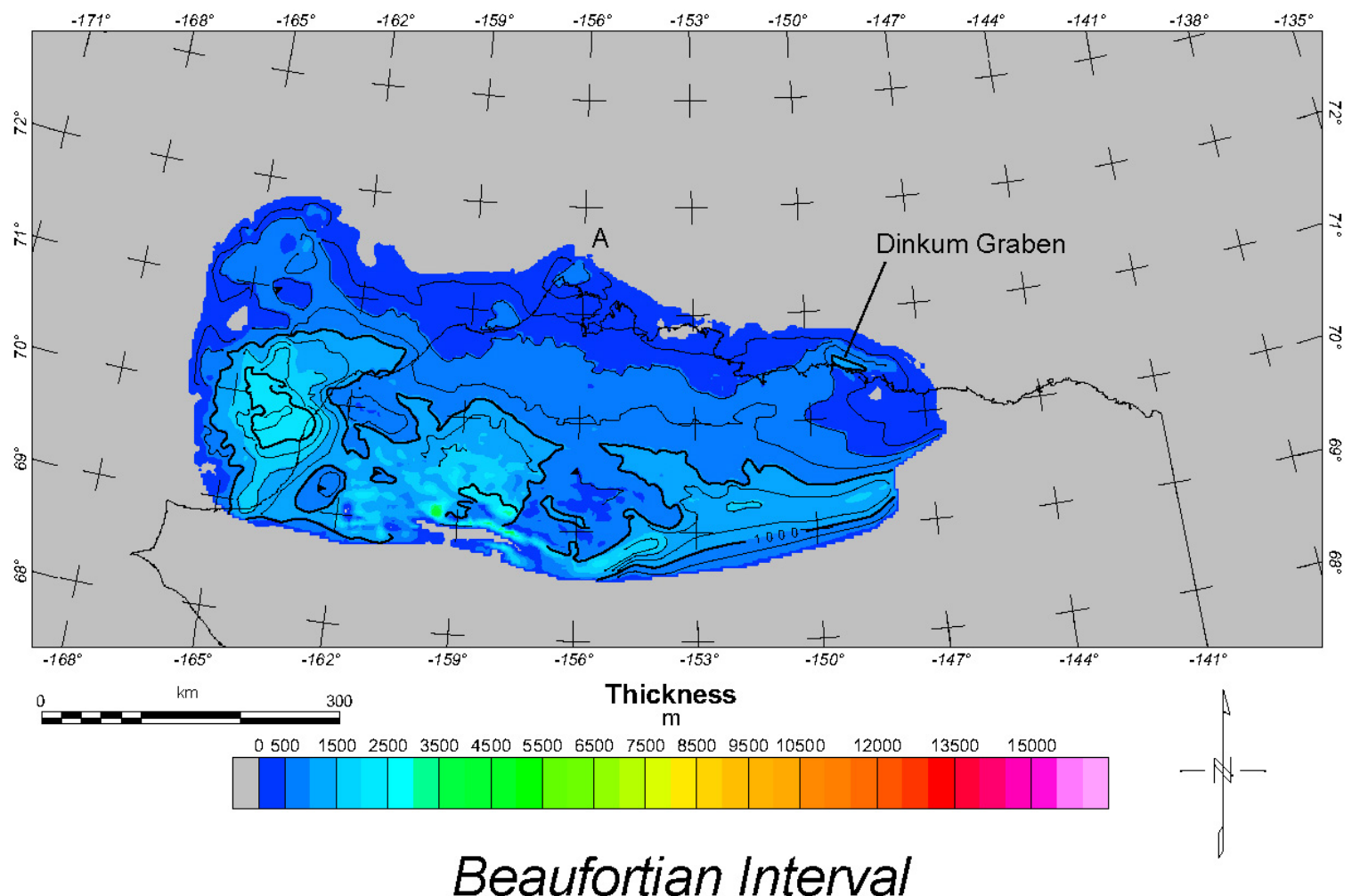

Figure 12 - Color contour isopach map of the Beaufortian stratigraphic interval. 


\section{Shublik to basement (Ellesmerian) interval}

The Ellesmerian section (Fig. 13) is thick in a band along the southern Colville Basin as well as in the Hanna Trough of the northwestern Chukchi Sea region (locations on Fig. 1). Compared with the earlier compilation by Hubbard and others (1990, Fig. 8), our compilation shows considerably more detail. The primary features identified by Hubbard and others (1990) are all visible in our compilation as labeled on Fig. 13. We show the Hanna Trough and the Utukok Basin to be considerably thicker than shown by Hubbard and others (1990). The narrow zone of thickened Ellesmerian section that lies southeast of the Ikpikpuk Basin is an artifact of uncertainties in mapping along the mountain front, we do not regard this as an actual feature.

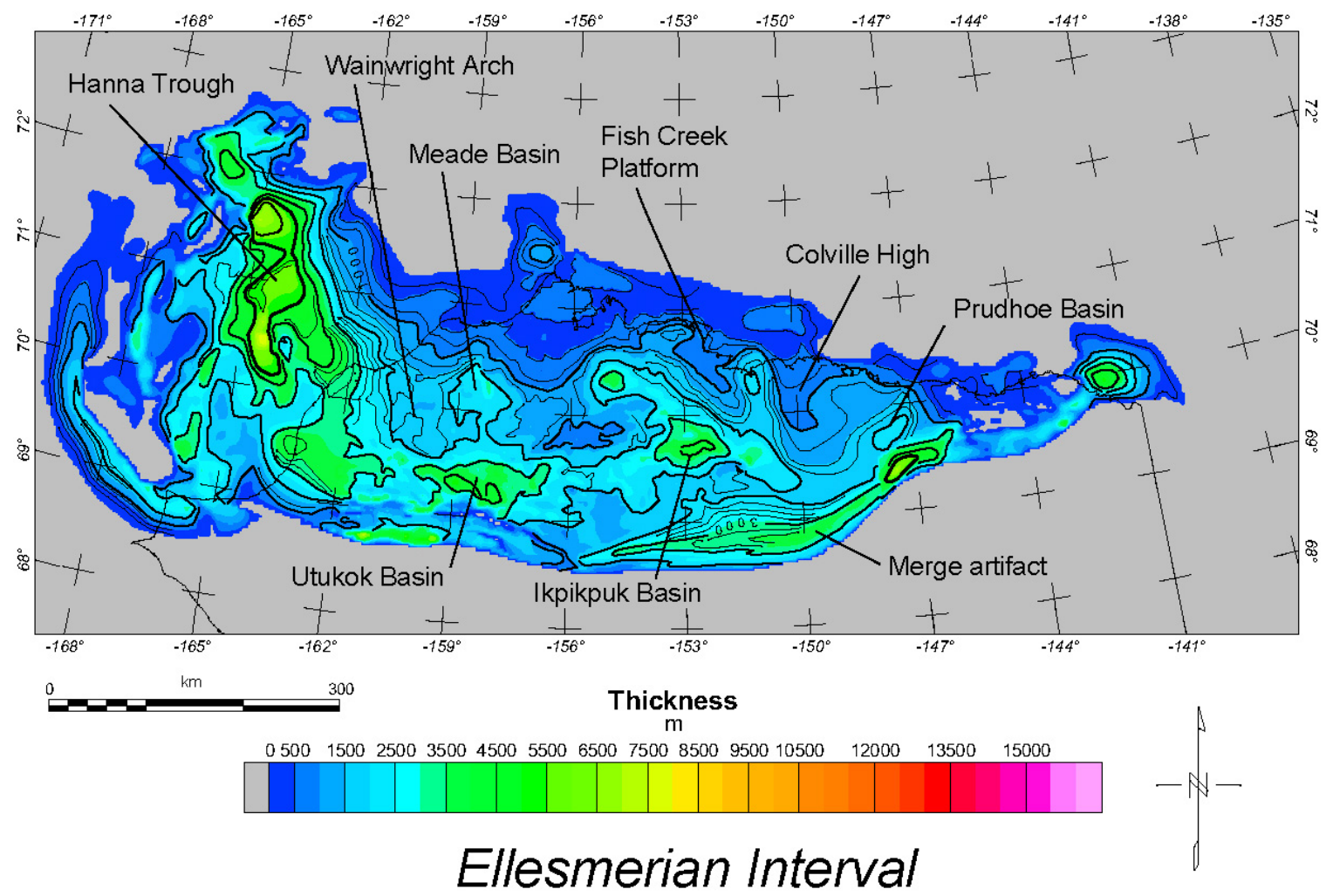

Figure 13 - Color contour isopach map of the Ellesmerian stratigraphic interval showing features labeled by Hubbard and others (1990) on their Ellesmerian isopach map. 


\section{Surface to Basement (entire sedimentary section)}

The total sediment thickness exceeds $12 \mathrm{~km}$ in the Colville Basin, the North Chukchi Basin and the offshore Nuwuk and Kaktovik Basins. Compared with the earlier compilation by Hubbard and others (1990) this map shows considerably more detail. The primary features labeled by Hubbard and others (1990, Fig. 5) are labeled on Fig. 14. In general, the features are similar to the earlier mapping (Hubbard and others, 1990). A notable exception is the offshore ridge (from Grantz and others, 1990, Fig. 4) that includes the Dinkum Plateau at the southeastern end of the Barrow Arch and separates the offshore Nuwuk and Kaktovik Basins (Fig. 14).

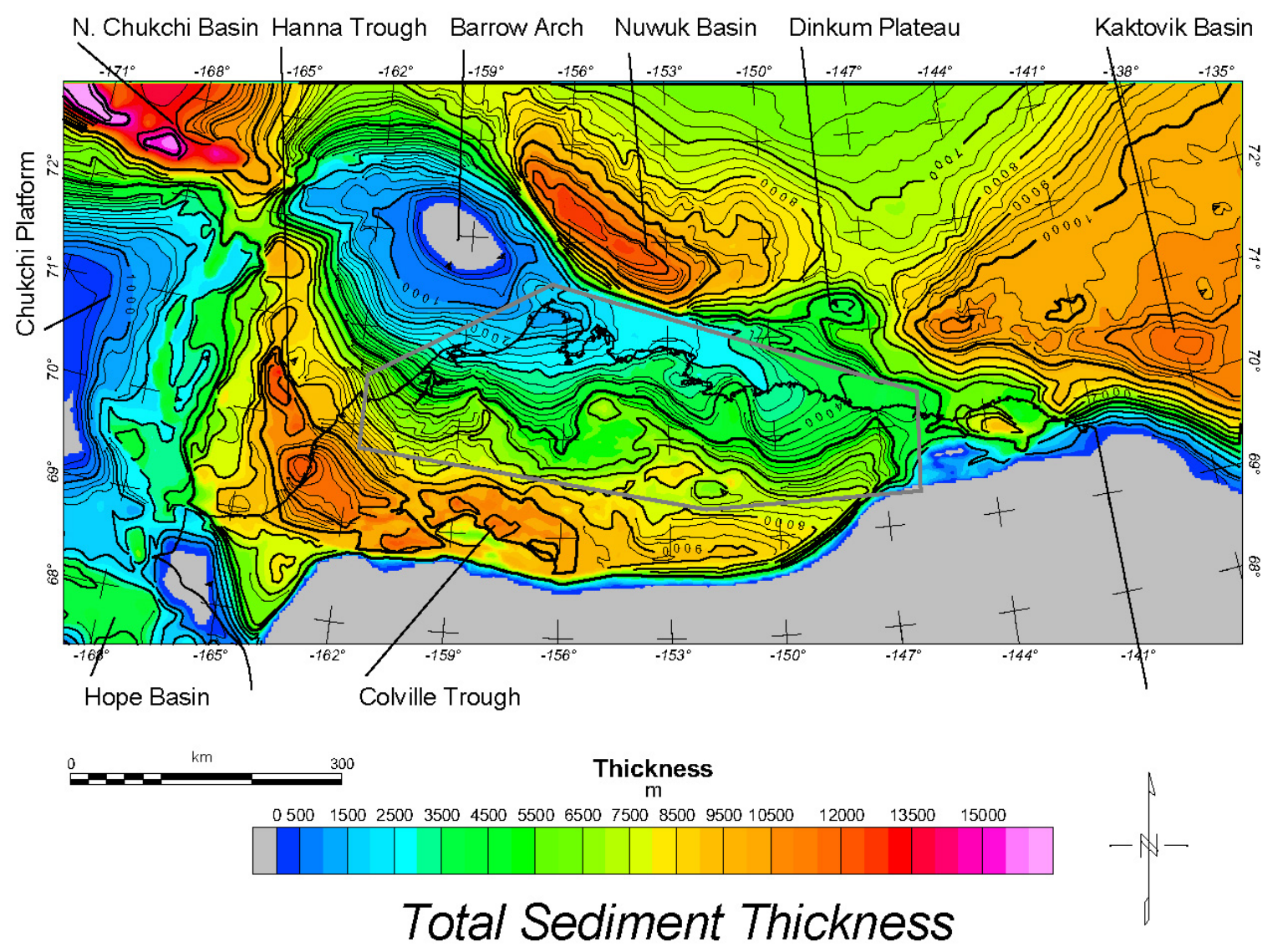

Figure 14 - Color contour isopach of total sediment thickness (surface to basement). 


\section{Digital data grids - description and statistics}

Summary statistics and other descriptive information for four depth horizon grids and four isopach grids are given in Table 1. These grids are available in several data formats in the download directory accompanying this report.

\begin{tabular}{|c|c|c|c|c|c|c|c|}
\hline \multicolumn{8}{|c|}{ Grid size $=435$ columns by 208 rows (total of 90480 grid cells) } \\
\hline \multicolumn{8}{|c|}{ Grid spacing $=3000 \mathrm{~m}$ in $\mathrm{X}$ and $\mathrm{Y}$} \\
\hline \multicolumn{8}{|c|}{ All elevations in meters } \\
\hline \multicolumn{8}{|c|}{ Projection: Alaska Albers (central meridian $=-154$, base latitude $=50$, std parallels $=55,65$ ) } \\
\hline \multicolumn{8}{|c|}{ Datum: NAD27 } \\
\hline \multicolumn{8}{|c|}{ Grid origin (in meters, projected) $=-630000,2000000$} \\
\hline \multicolumn{8}{|c|}{ ELEVATION HORIZONS } \\
\hline NAME & DESCRIPTION & MIN & MAX $\quad$ & MEAN I & MEDIAN & STDEV & \\
\hline NStopo & Topography/bathymetry & -3880 & 2104 & -531 & -39 & 1377 & \\
\hline NSlcu & Lower Cretaceous Unconf. & -16681 & 2104 & -5098 & -3808 & 4713 & \\
\hline NSshublik & Top of Shublik & -16681 & 2104 & -5295 & -4228 & 4700 & \\
\hline NSbasement & Top of pre-Carboniferous & -16881 & 2104 & -5912 & -5895 & 4730 & \\
\hline \multicolumn{8}{|l|}{ ISOPACHS } \\
\hline NAME & DESCRIPTION & MAX & MEAN & MEDIAN & STDEV & AREA km^2 & VOL km^3 \\
\hline NStopo-LCU & Brookian interval & 16603 & 4566 & 3871 & 3769 & 808,506 & $3.7 \mathrm{E}+06$ \\
\hline NSLCU-Shublik & Beaufortian interval & 4430 & 197 & 197 & 431 & 266,616 & $1.6 \mathrm{E}+05$ \\
\hline NSshublik-basement & Ellesmerian interval & 7925 & 617 & 1356 & 1127 & 320,175 & $5.0 \mathrm{E}+05$ \\
\hline NStopo-basement & Entire sedimentary interval & 16603 & 5380 & 5879 & 3926 & 808,506 & $4.3 \mathrm{E}+06$ \\
\hline
\end{tabular}

Table 1 - North Slope regional grid information and statistics

\section{Discussion}

Evaluation of undiscovered oil and gas resources may certainly be accomplished in a piecemeal, sub-regional basis, but evaluation of an entire basin without regard to political boundaries is a more scientifically rigorous. The ANWR 1002 area, NPRA, state lands portions of the Alaskan North Slope, and the (federal) offshore are all sub-regions that are being or have been separately evaluated. A region-wide approach with emphasis on petroleum systems as described in Magoon and Dow (1994) is the ultimate goal.

Modern, computer-based resource assessment requires the digitization, assembly, editing, and interpretation of three-dimensional geologic information. The four depth horizons assembled for this report provide a basic framework for modeling of regional fluid flow and, in areas of sufficient data density, for estimation of area and volume of possible trapping structures.

Although the four depth horizon grids presented here have been defined over the entire study area, the mapping accuracy is not uniform throughout the area. Seismically 
determined depths are generally accurate to approximately $\pm 10 \%$ assuming that the correct seismic interface is identified on the seismic section. We expect that within the Chukchi, NPRA, and ANWR portions of these data compilations that the mapped elevations are broadly within $\pm 10 \%$ of the actual depths. Horizon elevations within the central state lands region have been estimated from extrapolation with limited well depth control and are probably less accurate in detail, perhaps $\pm 15 \%$. The offshore Arctic data regions are based on very sparse seismic data coverage and are the least accurately mapped portions of these compilations.

All three subsurface depth horizons clearly reflect the prominent Barrow Arch and adjacent deep Colville Trough (Fig. 1). To the south the Colville Trough is overthrust by the Brooks Range. To the southwest, the Colville Trough merges into the Hanna Trough and terminates against the Herald Arch and Chukchi Platform. The Barrow Arch terminates to the southeast so that a significant shallow sedimentary section is present off the end of the arch in the eastern state lands and in the northwestern ANWR 1002 area. To the north of the Barrow Arch the Nuwuk Basin represents a thick accumulation of Brookian (and Beaufortian?) sedimentary rocks that overlies the basement of the continental shelf and, in the east, a great thickness of sedimentary rock is present in the Kaktovik Basin. These offshore basins thin northward into the Canadian Basin.

\section{References}

ANWR Assessment Team, 1998, The Oil and Gas Resource Potential of the Arctic National Wildlife Refuge 1002 Area, Alaska: U.S. Geological Survey Open File Report 98-0034 (http://energy.cr.usgs.gov/OF98-34/).

Bird, K. J., 1988, Alaskan North Slope stratigraphic nomenclature and data summary for government-drilled wells, in Gryc, G., ed., Geology and exploration of the National Petroleum Reserve in Alaska, 1974 to 1982: U. S. Geological Survey Professional Paper 1399, p. 317-354.

Bird, K.J., and Houseknecht, D.W., 2002, U.S. Geological Survey 2002 Petroleum Resource Assessment of the National Petroleum Reserve in Alaska (NPRA): Play Maps and Technically Recoverable Resource Estimates: U.S. Geological Survey Open-file report 02-0207 (http://wrgis.wr.usgs.gov/open-file/of02-207/).

Briggs, I.C., 1974, Machine contouring using minimum curvature: Geophysics, v. 39, n. 1, p. 39-48.

Bruynzeel, J. W., Guldenzoph, E. C., and Pickard, J. E., 1982, Petroleum exploration of NPRA, 1974-1981-Final Report: Houston, Tetra Tech, Inc., report 8200, 3 vols., 5 boxes of geophysical maps. [Available from National Geophysical Data Center, 325 Broadway, E/GC, Dept. CNP, Boulder, CO 80303]. 
Craig, J.D., Sherwood, K.W., and Johnson, P.P., 1985, Geologic report for the Beaufort Sea planning area, Alaska-Regional geology, petroleum geology, environmental geology: Minerals Management Service OCS Report MMS 85-0111, p. 192.

Grantz, Arthur, and May, S. D., 1988, Regional geology and petroleum potential of the United States Chukchi sea self north of Point Hope, in Gryc, G., ed., Geology and exploration of the National Petroleum Reserve in Alaska, 1974 to 1982: U. S. Geological Survey Professional Paper 1399, p. 209-230.

Grantz, A., May, S.D., and Hart, P.E., 1990a, Geology of the Arctic Continental Margin of Alaska: in Grantz, A., Johnson, L., and Sweeney, J.F., eds., The Arctic Ocean Region, The Geology of North America, Volume L, The Geological Society of America, Boulder, CO, p. 257-288.

Grantz, A., May, S.D., Taylor, P.T., and Lawver, L.A., 1990b, Canada basin, in Grantz, A., Johnson, G.L., and Sweeney, J.F., eds., The Arctic Ocean region: Boulder, Colorado, Geological Society of America, The Geology of North America, vol. L, p. 379-402.

Grantz, A., Scholl, D.W., Toro, J., and Klemperer, S.L., 2002, Geologic structure of Bering and Chukchi shelves adjacent to Bering-Chukchi deep seismic transect and tectonostratigraphic terranes of adjacent landmasses: in Tectonic Evolution of the Bering Shelf-Chukchi Sea-Arctic Margin and Adjacent Landmasses, Miller, E.L., Grantz, A., and Klemperer, S.L., eds, Plate 1, scale 1:3,000,000.

Hubbard, R.J., Edrich, S.P., and Rattey, R.P., 1990, Geological evolution and hydrocarbon habitat of the "Arctic Alaska Microplate", in Classic Petroleum Provinces, Brooks, J., ed., London Geological Society Special Publications, vol. 50, p. 143-187.

Jackson, H.R., and Oakey, G.N., 1990, Sedimentary thickness map of the Arctic ocean: in Grantz, A., Johnson, L., and Sweeney, J.F. (eds), The Arctic Ocean Region, The Geology of North America, Volume L, The Geological Society of America, Boulder, CO, scale $1: 5,000,000$, plate 5 .

Lampe, C., Peters, K.E., Magoon, L.B., Bird, K.J., Lillis, P.G., 2003, The Shublik’s petroleum systems of the Alaskan North Slope - a numerical journey from source to trap: American Association of Petroleum Geologists Annual Convention Official Program (May 11-14, 2003), v. 12, p. A98.

Magoon, L.B., and Dow, W.G., eds., 1994, The petroleum system-From source to trap, American Association of Petroleum Geologists Memoir 60, 655 p.

Moore, T.E., Wallace, W.K., Bird, K.J., Karl, S.M., Mull, C.G., and Dillon, J.T., 1994, Geology of northern Alaska: in Plafker, G., and Berg, H.C., eds., The Geology of Alaska: DNAG volume G-1, p. 49-140. 
Pessel, G., Tailleur, I.L., and Levorsen, J.A., 1978, Generalized structure map of top of Sag River Sandstone, eastern North Slope petroleum province, Alaska: U.S. Geological Survey Miscellaneous Field Studies Map MF-928 L, 1 sheet, scale 1:500,000.

Saltus, R.W., and Bird, K.J., 2003, North Alaska petroleum system analysis - the regional map compilation: American Association of Petroleum Geologists Official Program 2003 Annual Convention (May 11-14, 2003), v. 12, p. A150-A151.

Saltus, R.W., Kulander, C.S., and Potter, C.J., 2002, Digital recovery, modification, and analysis of Tetra Tech seismic horizon mapping, National Petroleum Reserve Alaska (NPRA), northern Alaska: U.S. Geological Survey Open-File report 02-0111. Available at http://geology.cr.usgs.gov/pub/open-file-reports/ofr-02-0111/.

Saltus, R.W., Hudson, T.L., and Phillips, J.D., 2001, Basement geophysical interpretation of the National Petroleum Reserve Alaska (NPRA), northern Alaska: U.S. Geological Survey Open-File Report 01-0476, 3 poster panels with supplementary text (http://geology.cr.usgs.gov/pub/open-file-reports/ofr-01-0476/)

Sherwood, K.W., Craig, J.D., Lothamer, R.T., Johnson, P.P., and Zerwick, S.A., 1998, Chukchi Shelf Assessment Province, in Sherwood, K.W., ed., Undiscovered oil and gas resources, Alaska federal offshore (as of January 1995), U.S. Minerals Management Service OCS Monograph MMS 98-0054, p. 115-196.

Tailleur, I.L., Pessel, G., and Engwicht, S.E., 1978a, Subcrop map at Lower Cretaceous unconformity, and maps of Jurassic and Lower Cretaceous seismic horizons, eastern North Slope petroleum province, Alaska: U.S. Geological Survey Miscellaneous Field Studies Map MF-928 I, 1 sheet, scale 1:500,000.

Tailleur, I.L., Bird, K.J., and Engwicht, S.E., 1978b, Map showing depth to basement from drilling and from seismic exploration, eastern North Slope petroleum province, Alaska: U.S. Geological Survey Miscellaneous Field Studies Map MF-928 U, 1 sheet, scale 1:500,000.

Tailleur, I., and Engwicht, S.E., 1978, Structure maps of top of Sadlerochit Group, and cross sections of Sadlerochit reservoir, eastern North Slope petroleum province, Alaska: U.S. Geological Survey Miscellaneous Field Studies Map MF-928 O, 1 sheet, scale 1:500,000. 


\section{APPENDIX A}

The following data files accompany this report. Each is provided in several data formats including Geosoft grid exchange format (*.gxf), ZMAP format (.dat), ASCII xyz format (*.xyz), and (for the primary horizon grids only) in Arc/Info export format (.e00). In addition each horizon or isopach is available in image form as an Arc Geotiff (*.tif, $*$.tfw).

1. Horizons
A. NStopo
B. NSLCU
C. NSshublik
D. NSbasement

2. Isopachs
A. NStopo-LCU (Brookian interval)
B. NSLCU-Shublik (Beaufortian interval)
C. NSshublik-basement (Ellesmerian interval)
D. Nstopo-basement (total sediment thickness) 